\title{
DAMAGE TO CIVIL ENGINEERING STRUCTURES
}

\author{
Masami FukuokA*
}

\section{GEOLOGY AND EARTHQUAKE}

Severe damage occurred in the alluvial plain near the coast of Japan Sea, Niigata, Yamagata, and Akita Prefectures. The mountainous region of this district mainly consists of the tertiary formation which have caused landslide, and other rocks which are volcanic ones such as andesite, liparite, basalt, etc. Shinano plain, where the damage was very large, lies at a distance between 50 to $70 \mathrm{~km}$ from the epicentre, and is an alluvial plain at the downstream of the Shinano River and the Agano River, Shonai plain, where the damage was also large, lies at a distance between 70 to $80 \mathrm{~km}$ from the epicentre, and is an alluvial plain at the downstream of the Mogami River. Thickness of a soft sand layer, the $\mathrm{N}$-value of which is smaller than 10 , is about $10 \mathrm{~m}$ in Niigata City. This sand layer is a sediment transported by the Shinano River and the Agano River. Niigata plain is shown in Fig. 1. Sand dunes are situated parallel

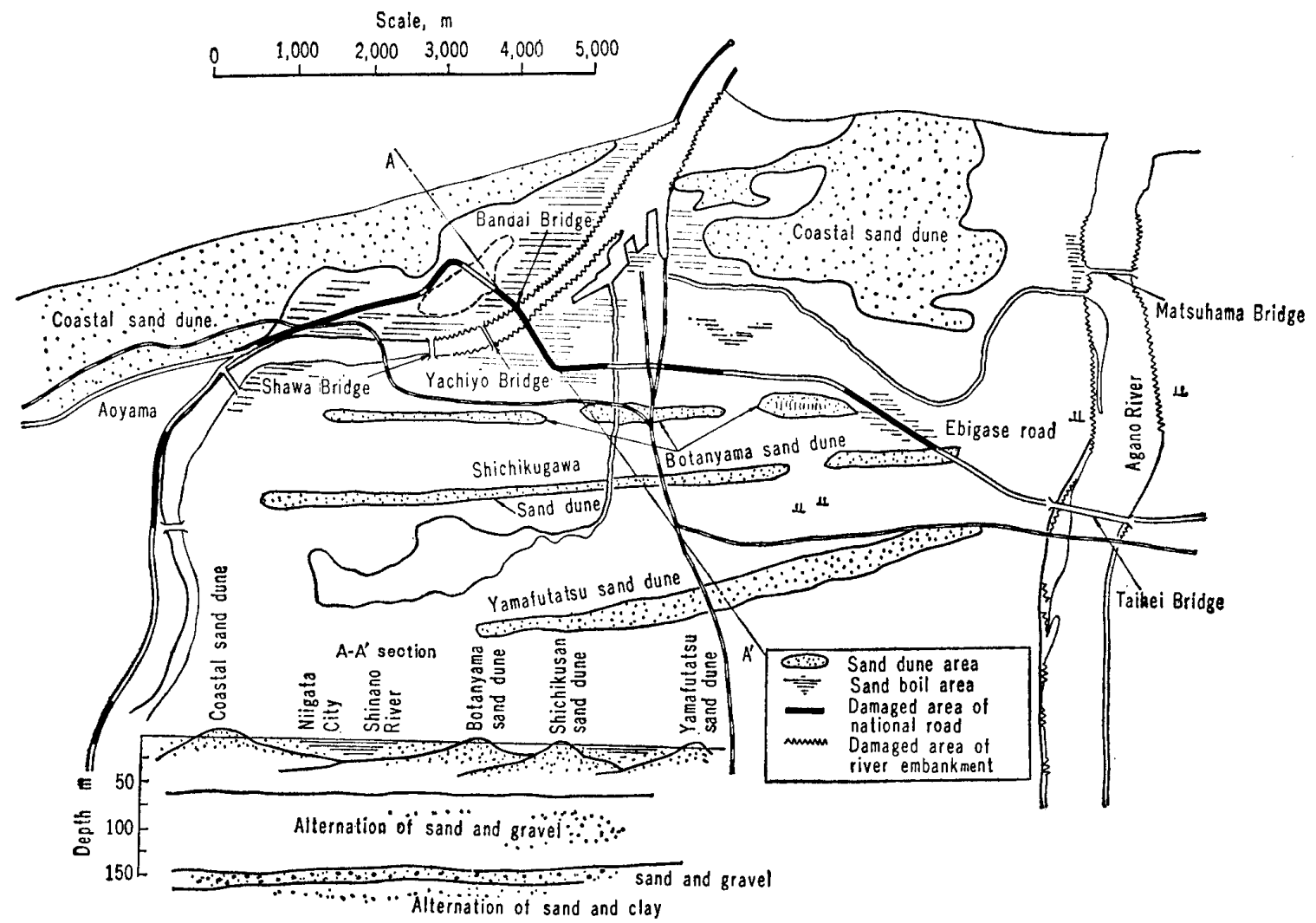

Fig. 1. Niigata Area

* Director of Public Works Research Institute, Ministry of Construction. 
to the sea coast. The height of these sand dunes, except the coastal sand dunes, is as low as other alluvial plain. The damage was very slight at the sand dune area. On the contrary, the heavy damage took place at the alluvial plain along the rivers. The sand boiled area and the damage sites along levees and national roads are also shown in Fig. 1. A landslide at Aoyama area was only the one which took place at coastal sand dune area. The $\mathrm{N}$-value of sand dune is about 10 20. The sand which spouted out of the ground in the old river bed areas is a blue, gray color. It is a uniformly graded medium sand, and its 60 per cent diameter, $D_{60}$, is about $0.3 \mathrm{~mm}$. Prof. Terzaghi and Peck reported some examples of quick sands in which the 60 per cent diameters were $0.06-0.1 \mathrm{~mm}$. Therefore, the spouted sand is little coarser than the quick sands.

\section{LIQUEFACTION OF THE GROUND AND DAMAGE TO STRUCTURES}

Liquefaction of the ground is a distinctive feature of the earthquake damage in Niigata area. It has not been clarified yet how the liquefaction phenomena took place. The liquefaction phenomena took place in an area where loose uniform sand $(\mathrm{N} \leqq 10)$ is deposited under the ground water.

Thickness of loose sand layer is more than $5 \mathrm{~m}$. It is reported that even the thickness is more than $10 \mathrm{~m}$, liquefaction phenomena do not take place if the layer contains a silt layer of more than $2 \mathrm{~m}$ thick. An object like a sewerage pipe and manhole, which has small bulk density $\left(0.35 \sim 1.20 \mathrm{t} / \mathrm{m}^{3}\right)$, rose to the ground surface, on the other hand, an object like an electric pole which has large bulk density went down.

Horizontal resistance of pile foundation reduces, therefore, a structure supported with pile foundation moves horizontally, and severe deformation and destruction take place. A slope begins to slide, and moreover a horizontal ground surface begins to move blockwise.

However, the relationship between sliding and liquefaction is not clear. Some remarkable damage to structures will be stated as follows.

1) Showa Bridge

Showa Bridge was completed about a month before the earthquake. This bridge has 12 composite girders, its breadth is about $24 \mathrm{~m}$, and its total length is about $307 \mathrm{~m}$. Main span length is about $28 \mathrm{~m}$, and side span length is about $15 \mathrm{~m}$. A bridge pier is composed of steel pipe piles. Diameter of the pile is $60 \mathrm{~cm}$, and thickness of it is 16 9 mm. Its profile is shown in Fig. 2, and its section is shown in Fig. 3. Settlement of access roads and displacement of abutment caused by a pushing out of river banks towards the river side took place, as observed at Bandai-bridge and Yachiyobridge. Unfortunately, five main spans out of ten fell down. A girder between Pier No. $5\left(\mathrm{P}_{5}\right)$ and Pier No. $6\left(\mathrm{P}_{6}\right)$ fell down completely and submerged into the river bed. Girders between $P_{2}-P_{3}, P_{3}-P_{4}, P_{5}-P_{6}, P_{6}-P_{7}$ inclined, fixed ends of the girders were remained on the top of pile piers, and movable ends dropped into the river. Upper parts of $P_{5}$ and $P_{6}$ above the river bed bent by about $90^{\circ} . P_{5}$ bent towards the left, and $P_{6}$ bent towards the right.

A pile of pier No. $4\left(\mathrm{P}_{4}\right)$ was taken out after the earthquake. It is shown in Fig. 4. 


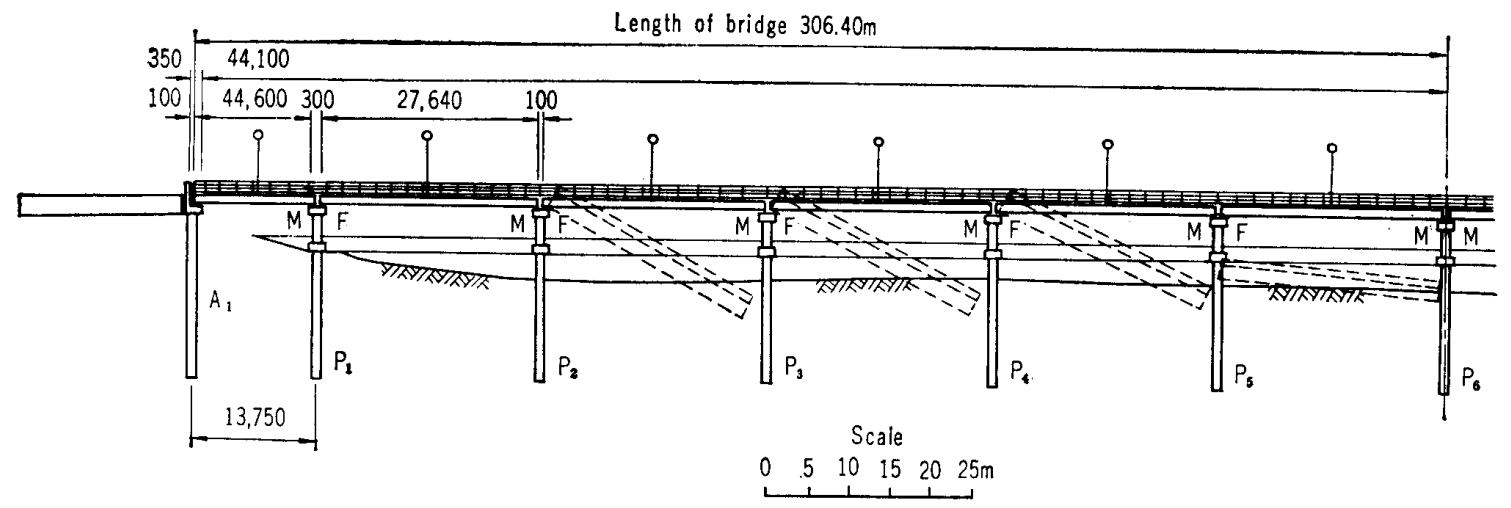

Fig. 2. Profile of Showa-bridge

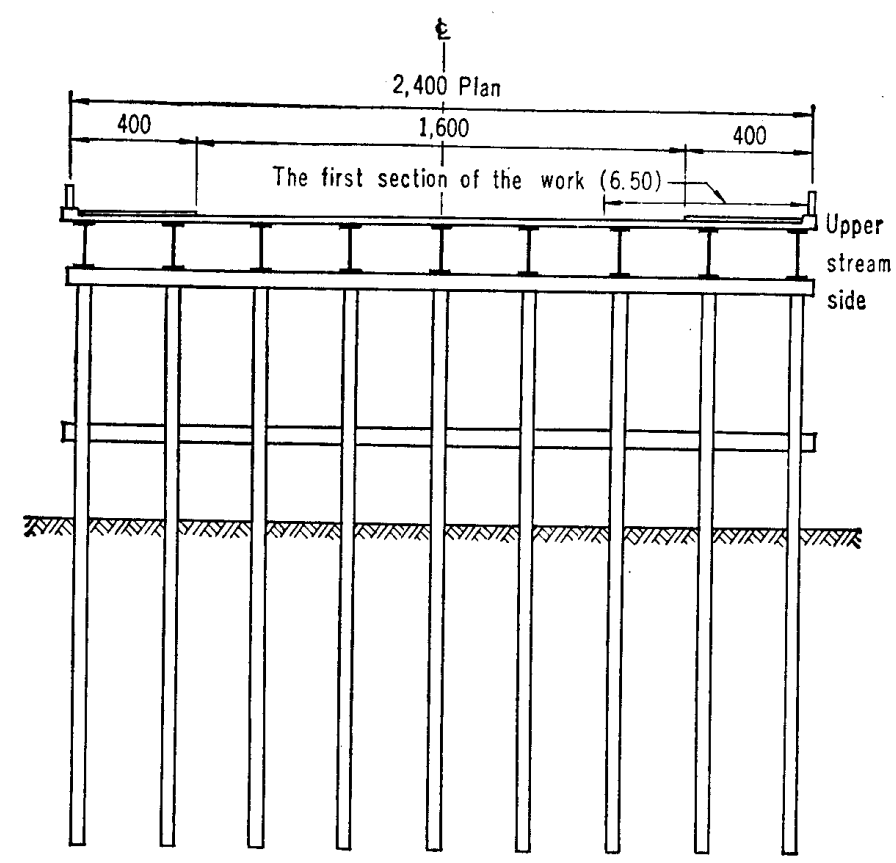

Fig. 3. Section of the Showa-bridge

This pile was bent at a part about $6 \mathrm{~m}$ from the bottom. Perhaps this was caused by $\mathrm{s}$ slide. A sliding surface is supposed to be between loose sand (medium or coarse sand, $N \leqq 10$ ) and compact sand (fine sand, $N \leqq 30$ ). Immediate cause of falling down of the girder is supposed to be bending of $P_{6}$. Trace of buckling is found at a point shown in Fig. 4. This local buckling was supposed to be caused by the horizontal movement of the girder towards the left, before the sliding started. Frequency of Niigata earthquake was long and natural frequency of Showa-bridge was also long, therefore piles were to be bent strongly. The result of response spector analysis indicated a great possibility of an occurrence of the local buckling, since a response acceleration was found to be very large. The response acceleration at a top of the bridge pier is shown in Table 1 . 


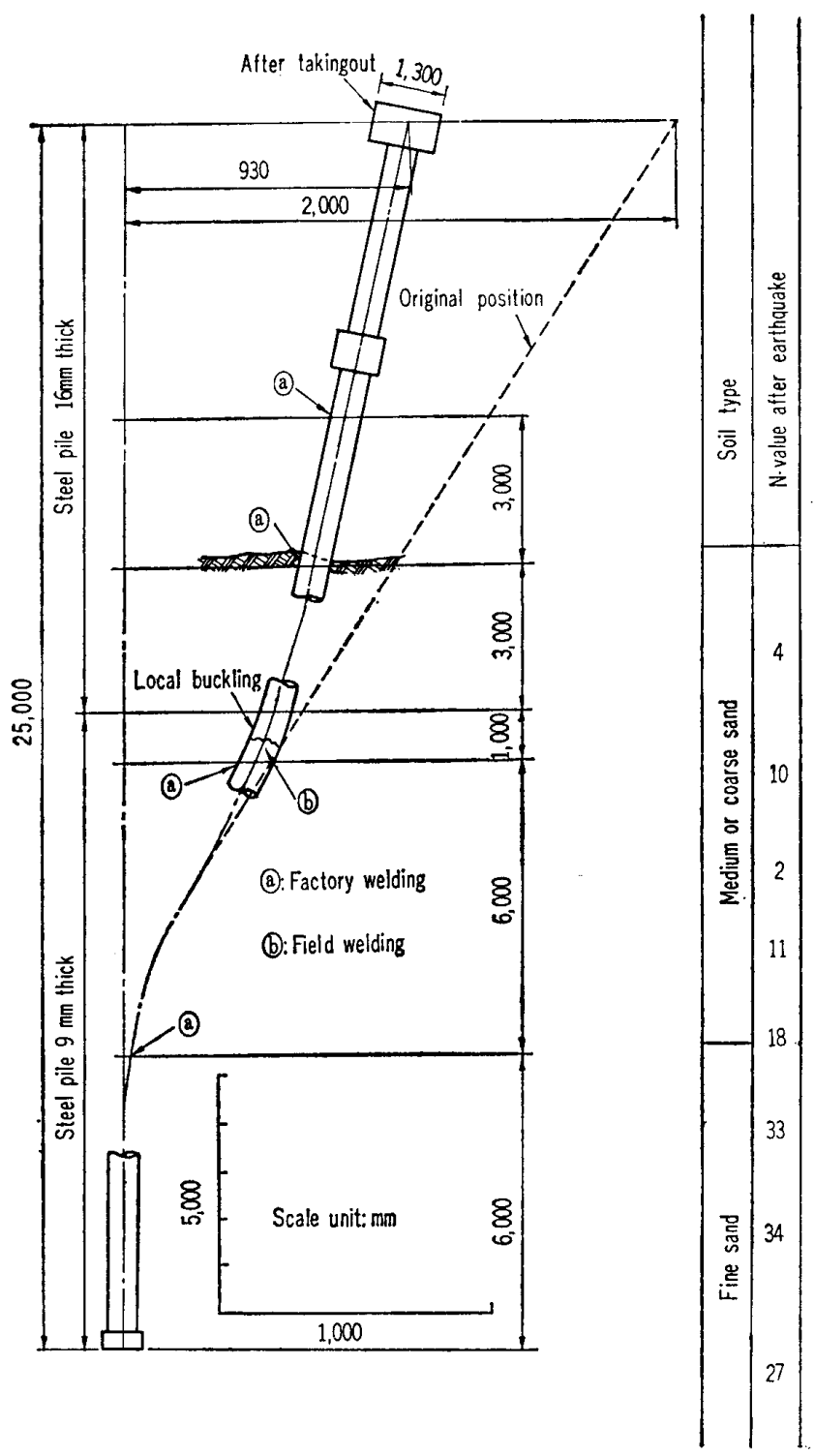

Fig. 4. Pipe Pier No. 4, taken out from the ground

Table 1.

\begin{tabular}{c|c|c|c}
\hline Spectorum used & $\begin{array}{c}\text { Maximum acceleration } \\
\text { of earthquake }\end{array}$ & $\begin{array}{c}\text { Response acceleration } \\
\text { at a pier top }\end{array}$ & $\begin{array}{c}\text { Relative displacement } \\
\text { between ground and } \\
\text { a pier top }\end{array}$ \\
\hline $\begin{array}{c}\text { Mean value of the past } \\
\text { seismograph records }\end{array}$ & $0.2 \mathrm{~g}$ & $0.184 \mathrm{~g}$ & $20.8 \mathrm{~cm}$ \\
\hline $\begin{array}{c}\text { Record of Niigata Earth- } \\
\text { quake N-S Direction }\end{array}$ & $0.14 \mathrm{~g}$ & $0.32 \mathrm{~g}$ & $41.5 \mathrm{~cm}$ \\
\hline
\end{tabular}

Note: Free length of a pier $l=8 \mathrm{~m}$. Horizontal $K$-value of ground $1.0 \mathrm{~kg} / \mathrm{cm}^{3}$, Damping factor $h=0.02$, Natural frequency of the bridge $T_{s}=2 \mathrm{sec}$, Frequency of Niigata Earthquake $T \fallingdotseq 3.5 \mathrm{sec}$. 
Table 2.

\begin{tabular}{|c|c|c|c|c|c|c|c|c|c|c|c|}
\hline \multirow[b]{2}{*}{$\begin{array}{l}\text { Depth } \\
\text { (m) }\end{array}$} & \multirow[b]{2}{*}{$\begin{array}{c}\begin{array}{c}\text { Unit } \\
\text { Weight }\end{array} \\
(\mathrm{g} / \mathrm{cm})^{\mathrm{s}}\end{array}$} & \multirow[b]{2}{*}{$\begin{array}{c}\begin{array}{c}\text { Dry } \\
\text { Density }\end{array} \\
\left(\mathrm{g} / \mathrm{cm}^{8}\right)\end{array}$} & \multirow[b]{2}{*}{$\begin{array}{c}\text { Specific } \\
\text { Gravity } \\
G_{s}\end{array}$} & \multirow[b]{2}{*}{$\begin{array}{c}\text { Void } \\
\text { Ratio } \\
e\end{array}$} & \multicolumn{7}{|c|}{ Grain size Distribution } \\
\hline & & & & & $\begin{array}{c}\text { Gravel } \\
(\%)\end{array}$ & $\begin{array}{l}\text { Sand } \\
(\%)\end{array}$ & $\begin{array}{l}\text { Silt } \\
(\%)\end{array}$ & $\begin{array}{l}\text { Clay } \\
(\%)\end{array}$ & $\begin{array}{c}60 \% \\
\text { dia- } \\
\text { meter } \\
D_{60}\end{array}$ & $\begin{array}{c}10 \% \\
\text { dia- } \\
\text { meter } \\
D_{10}\end{array}$ & $\begin{array}{c}\text { Uni- } \\
\text { foamity } \\
\text { Coef- } \\
\text { ficient } \\
U_{c}\end{array}$ \\
\hline $2.15-2.47$ & - & - & 2.63 & - & 0.5 & 86.0 & 5.5 & 8.0 & 0.22 & 0.03 & 7.33 \\
\hline $3.00-3.80$ & 1.963 & 1.195 & 2.66 & 1.23 & 0 & 94.1 & (5.9) & & 0.32 & 0.11 & 3.0 \\
\hline $5.00-$ & 1.856 & 1.543 & 2.66 & 0.72 & 2.2 & 96.3 & $(1.5)$ & & 0.49 & 0.24 & 2.0 \\
\hline $7.00-7.30$ & 1.81 & 1.36 & 2.65 & 0.95 & 9.0 & 85.5 & 3.5 & 2.0 & 1.20 & 0.22 & 5.45 \\
\hline $7.30-7.60$ & 1.94 & 1.58 & 2.65 & 0.68 & 0.5 & 97.0 & 2.5 & 0 & 0.37 & 0.19 & 1.95 \\
\hline $11.00-11.57$ & 1.82 & 1.42 & 2.63 & 0.85 & 0 & 97.0 & 3.0 & 0 & 0.31 & 0.165 & 1.88 \\
\hline $13.00-13.58$ & 2.59 & 1.719 & 2.69 & 0.56 & 0 & 97.1 & $(2.9)$ & & 0.24 & 0.06 & 2.13 \\
\hline $12.27-17.55$ & 2.01 & 1.61 & 2.72 & 0.69 & 0 & 84.0 & 11.0 & 5.0 & 0.16 & 0.05 & 3.42 \\
\hline
\end{tabular}

Boring and sampling were made after the earthquake. A result of soil testing is shown in Table 2. As a result of triaxial compression test, a critical void ratio of coarse sand is found to be 0.8 , and critical dry density $1.5 \mathrm{~g} / \mathrm{cm}^{8}$.

2) Yachiyo-Bridge

Yachiyo-bridge, which is about $500 \mathrm{~m}$ down from Showa-bridge, did not fall down.

A concrete pile of a pier taken out from the right bank is shown in Figs. 5 and 6. The diameter of this concrete pile is $60 \mathrm{~cm}$, and spacing of cracks is about $30 \mathrm{~cm}$. A top of a pile is embedded in a footing. The embedded part did not break unexpectedly. A pier $\left(P_{9}\right)$ moved about $50 \mathrm{~cm}$ horizontally, but no sign of inclination could be found. This is caused by a horizontal sliding of the ground in the river. A girder almost fell down by the movement of the pier.

3) Horizontal Displacement of Ebigase Roads

Ebigase Road shown in Fig. 1. is in the old river bed of the Agano-river. Severe meandering of a straight road took place, and sinking of the road surface was observed as the result of the earthquake. Horizontal and vertical displacement of the road is shown in Fig. 7. The maximum horizontal displacement was $5.10 \mathrm{~m}$, and the maximum settlement was $1.134 \mathrm{~m}$.

According to the boring and sounding, 7 to $8 \mathrm{~m}$ below the ground surface is loose sand, and compact fine sand is found under this layer. This condition is quite similar to that of Showa-bridge. Therefore, we can imagine that a sliding took place along a surface at 7 to $8 \mathrm{~m}$ below the ground surface. Existence of a horizontal sliding surface was proved by observing bending of pipes for natural gas mine. 


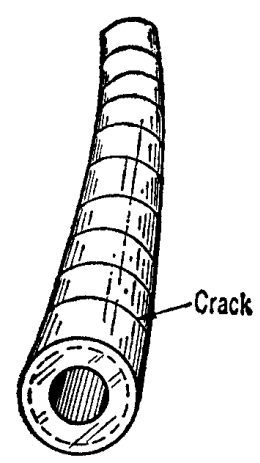

Fig. 5. Cracks of precast reinforced concrete pile

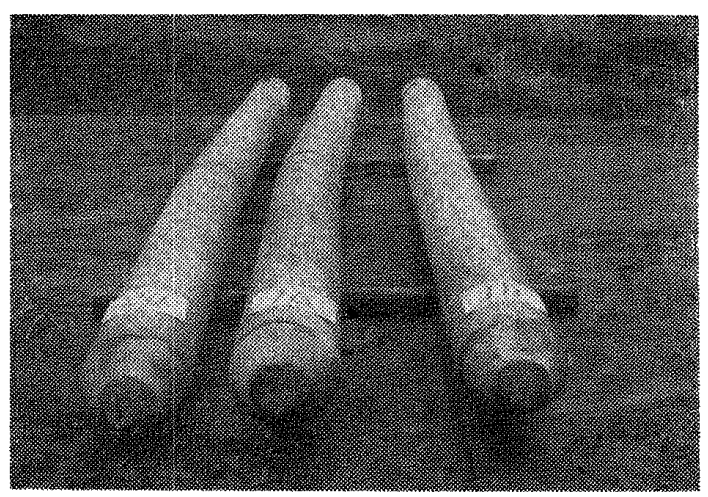

Fig. 6 (a). Precast reinforced concrete piles

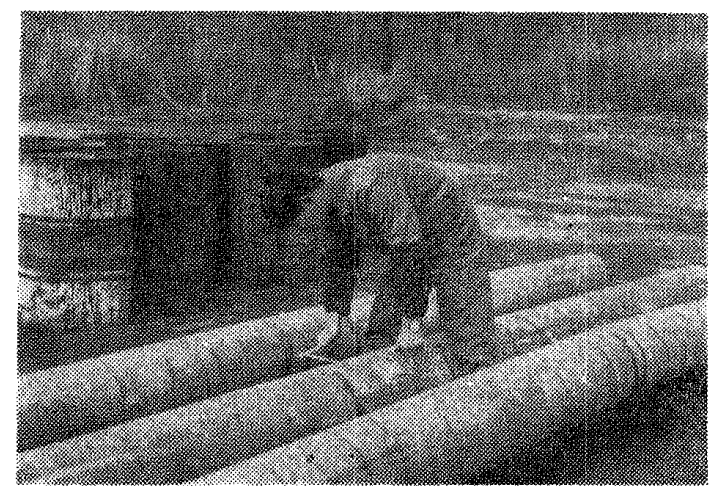

Fig. 6 (b). Precast reinforced concrete piles
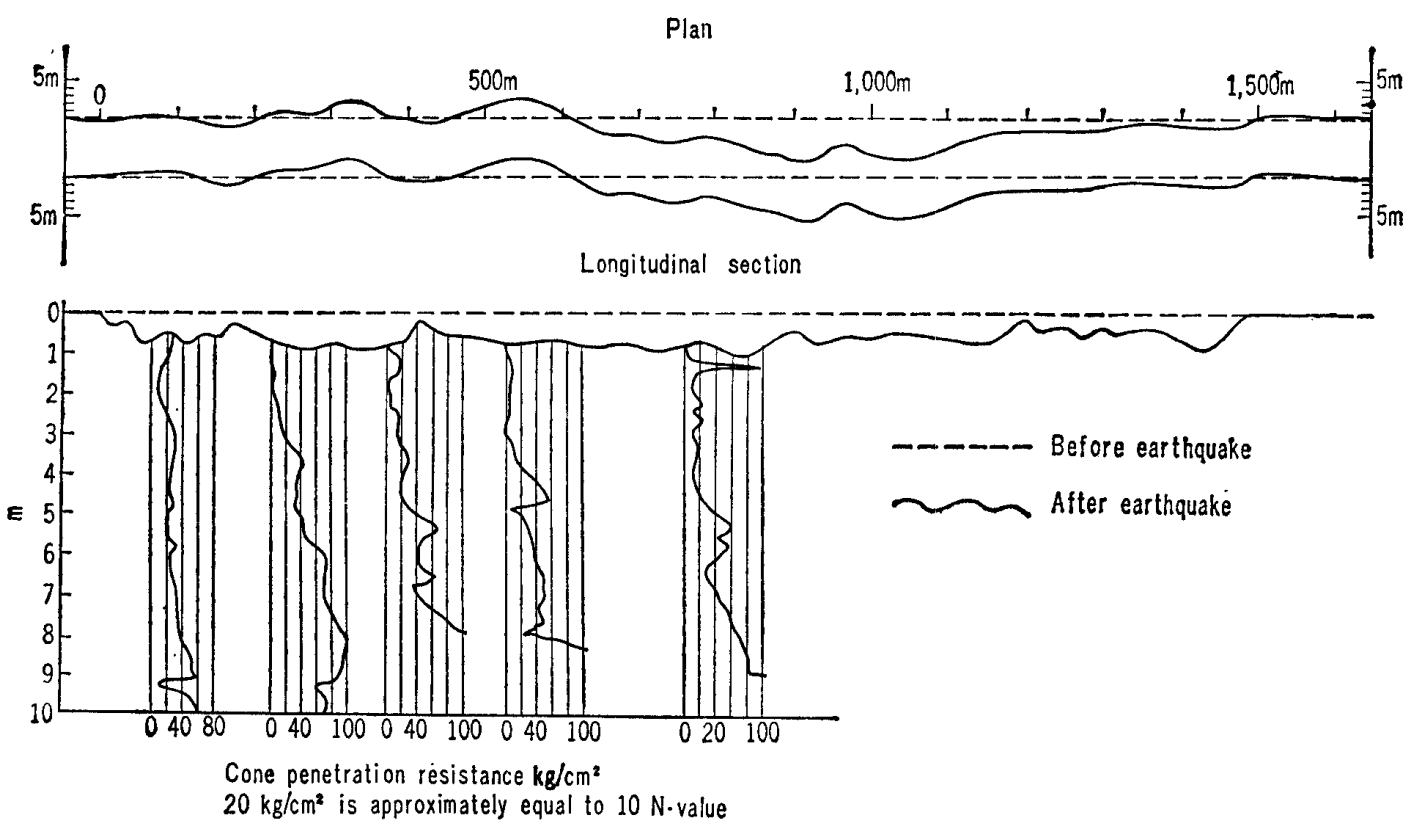

Fig. 7. Horizontal and vertical displacement of Ebigase Road 
VOL. VI, NO. 2, 1966

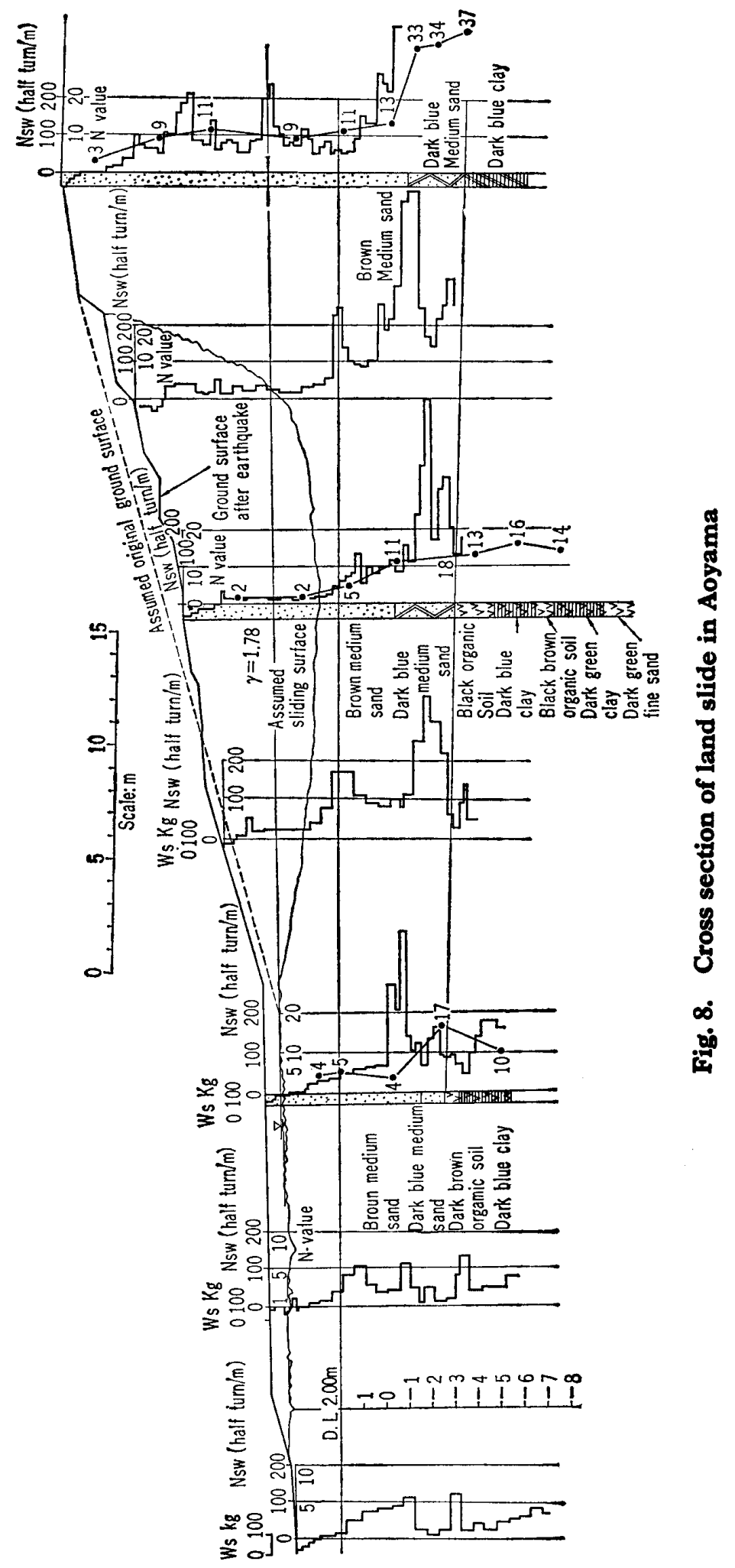




\section{SLIDING OF SLOPES}

As observed in other earthquakes, sliding of slopes like natural slopes and embankments took place. An example of landslide of natural slope at sand dune in Aoyama region is shown in Fig. 8. Generally sand dune is relatively compact, and ground water level is low compared with a plain. However, thickness of low $\mathrm{N}$-value layer is relatively large here. A landslide took place for this reason perhaps. Using a popular slip circle method in Japan, a stability calculation was made. The result showed that a sliding was to begin when a horizontal seismic force of $0.2 \mathrm{~g}$ was applied. But a sliding surface traced by field sounding test was not of circular shape as shown in Fig. 8.

The result of stability analysis applied to a levee shows that the levee begins to slide when horizontal seismic force becomes about $0.2 \mathrm{~g}$. These results suggest the validity of the existing popular method of analysis. The reason why some slopes did not slide though the condition was quite similar to slid slopes, has not been cleared up yet. Therefore, a future research work should be done.

\section{CONCLUSION}

Many people reported that the Niigata earthquake was characterized by the liquefaction phenomena. A sliding which took place in a horizontal ground, is reported in this paper. This is another remarkable finding this time. The sliding of this type changed shape and area of ground surface, moreover, it bent foundation piles and destroyed structures upon them. It destroyed earth structures like a retaining wall and an embankment.

This paper is prepared as the result of investigational work done by the Public Works Research Institute, Ministry of Construction. 